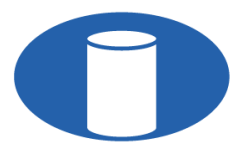

IBRACON

ORIGINAL ARTICLE

\title{
Application of the Analytic Hierarchy Process (AHP) to select high performance concretes
}

\section{Aplicação do método da análise hierárquica para escolha de concretos de alto desempenho}

Sabrina Requião Pinto ${ }^{a}$

Diogo Henrique de Bem ${ }^{a}$

Markus Samuel Rebmann ${ }^{\mathrm{b}}$

Marcelo Henrique Farias de Medeiros ${ }^{\mathrm{c}}$ (D)

\footnotetext{
${ }^{a}$ Universidade Federal do Paraná - UFPR, Departamento de Construção Civil - DCC, Programa de Pós-graduação em Engenharia Civil - PPGEC, Curitiba, PR, Brasil

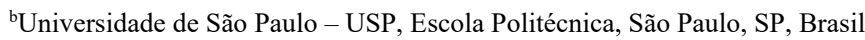

'Universidade Federal do Paraná - UFPR, Centro de Estudos em Engenharia Civil - CESEC, Departamento de Construção Civil - DCC, Curitiba, PR, Brasil
}

Received 26 March 2019

Accepted 07 July 2020

\begin{abstract}
This paper describes an application of the Analytic Hierarchy Process (AHP) to choose the best cement type and mixture for the production of high performance concrete. The decision process aimed at obtaining a concrete that would best meet the requirements of three hypothetical scenarios: (a) industrial concrete floors of a chemical plant, (b) structural elements of a thirty-floor building and (c) a massive foundation block of a green building. In this regard, six different concrete mixtures were evaluated (VR4, IIIR4, V280, III280, V200 and III210) according to four criteria: mechanical properties, durability, financial cost and environmental impact. The analysis results showed that the composition with CPV-ARI cement and content of $280 \mathrm{~kg} / \mathrm{m}^{3}$ was the best alternative for scenario (a) and (b), while for scenario (c) the composition with cement CPIII and content of $210 \mathrm{~kg} / \mathrm{m}^{3}$ was the best choice.
\end{abstract}

Keywords: high performance concrete, mechanical properties, economic and environmental performance, durability, analytic hierarchy process (AHP).

\begin{abstract}
Resumo: Este artigo apresenta uma aplicação do método da análise hierárquica na escolha do tipo de cimento e do traço para a produção de concretos de alto desempenho (CAD). O processo de decisão objetivou obter concretos que melhor atendessem as necessidades de três cenários: (a) piso industrial de uma fábrica de produtos químicos, (b) elementos estruturais de um edifício de 30 pavimentos e (c) um bloco de fundação de grande volume de um edifício com conceito sustentável. Para tal, a partir de seis alternativas de escolha (VR4, IIIR4, V280, III280, V200 e III210) foram avaliados 4 critérios: propriedades mecânicas, durabilidade, custo e impacto ambiental. Os resultados indicaram que a composição com cimento CPV-ARI e consumo de 280 $\mathrm{kg} / \mathrm{m}^{3}$ mostrou-se a melhor alternativa para os cenários (a) e (b), enquanto para o cenário (c) foi a composição com cimento CPIII e consumo de $210 \mathrm{~kg} / \mathrm{m}^{3}$.
\end{abstract}

Palavras-chave: concreto de alto desempenho, propriedades mecânicas, desempenho econômico e ambiental, durabilidade, processo de hierarquia analítica (AHP).

How to cite: S. R. Pinto, D. H. Bem, M. S. Rebmann, and M. H. F. Medeiros, “Application of the Analytic Hierarchy Process (AHP) to select high performance concretes," Rev. IBRACON Estrut. Mater., vol. 14, no. 2, e14206, 2021, https://doi.org/10.1590/S1983-41952021000200006

Corresponding author: Marcelo Henrique Farias de Medeiros. E-mail: medeiros.ufpr@gmail.com

Financial support: None.

Conflict of interest: Nothing to declare. 


\section{INTRODUCTION}

The emergence of a worldwide tendency to privilege design aspects aimed at the durability and extension of the service life of reinforced and prestressed concrete structures was mainly stimulated by factors such as the increasing occurrence of early degradation problems in concrete structures and the increased interest for more sustainability in the Civil Construction sector [1]. This durability is basically summarized as the structure's ability to satisfactorily withstand the environmental influences previously planned and defined by the designer and the contractor [2], that is, the interaction between the concrete structure, the environment and the conditions of use, operation and maintenance [3]. In view of this scenario, there is a strong tendency to study and develop special concretes such as high performance concrete (HPC), which is not necessarily a high strength concrete, but rather a concrete that has high durability in its conditions of use. In this field, prominent works include: Aitcin [4], Sorelli et al. [5], Cordeiro et al. [6], Shi et al. [7], Zhutovsky and Kovler [8], Sirtoli et al. [9], Shen et al. [10].

In addition to the materials commonly used in the production of conventional concretes, the composition of HPC differs in that it also incorporates mineral additions, such as fly ash, silica fume or metakaolin, in addition to chemical additives, especially of the superplasticizer type. According to Jucá et al. [11], the use of these mineral additions is motivated by reasons such as improving the rheological properties of fresh concrete with finer particles, thus reducing exudation and segregation, in addition to less permeability to aggressive agents such as chlorides and carbon dioxide due to the reduction of pores in the microstructure of the cement matrix. In this sense, in order to achieve better durability properties, studies in the literature have evaluated the production of concretes with low cement content and high levels of additions, usually fly ash or blast furnace slag. However, because they are less reactive additions than metakaolin and silica fume, they tend to generate lower final resistances. Celik et al. [12] noticed that replacing up to $65 \%$ of the cement paste with a combination of volcanic ash and limestone filler reduced the coefficient of chloride permeability by $50 \%$ both at 28 and 360 days, despite obtaining lower resistances. In other studies, it was also observed that the increased substitution of cement by blast furnace slag at levels of up to $80 \%$ was able to promote a reduction in chloride permeability, creep and concrete shrinkage [13], although there is also a reduction of mechanical resistances [14].

The use of additions to concrete is also a good solution from an environmental point of view. According to Worrell et al. [15], for the production of one ton of cement, about $814 \mathrm{~kg}$ of carbon dioxide $\left(\mathrm{CO}_{2}\right)$ is released into the atmosphere, and this emission comes basically from the clinker production process. The substitution of clinker for additions proportionally reduces the amount of polluting emissions per ton of binder, thus ensuring a lower $\mathrm{CO}_{2}$ rate per MPa of the concrete produced, provided that there is no drop in resistance [16]. Moreover, the content of many additions (when they are industrial waste) also makes these by-products more environmentally friendly. Additionally, the use of high performance concretes has a great advantage in terms of durability of the structures, thus ensuring a longer service life and less need for repairs and maintenance.

In this context, considering that there is a well-established association between $\mathrm{CO}_{2}$ emissions and environmental changes, in particular global warming, there is a continuing socio-environmental need to reduce industrial $\mathrm{CO}_{2}$ emissions, justifying strategies aimed at reducing cement content in concrete [17]. In this line of reasoning, the work of Felix and Possan [18] highlights the importance of considering the capture of carbon dioxide due to the carbonation process of concrete. This conduct of the previous work follows a line that corroborates the work of Silva et al. [19], which defends strategies for reducing the environmental impact of concrete and argues that the evaluation of concrete production chain sustainability should not be restricted to the assessment of $\mathrm{CO}_{2}$ emissions, but it is necessary to consider a global assessment with the application of the Life Cycle Assessment (LCA). Within this line of action there are studies for the development of concretes with low cement content, generally based on the theory of optimization of particle packing, such as the works of Varhen et al. [20], Grazia et al. [21], [22], Campos et al. [17], [23].

\section{CONTEXT OF THE ANALYTIC HIERARCHY PROCESS}

Due to its versatility, high-performance concrete has been adopted as a solution in offshore oil drilling platforms, long span bridges, viaduct decks [24], high-resistance industrial floors, garages, chemical product warehouses, spillways and energy dissipation structures in dams [25]. Also noteworthy is the use of HPC in tall building structures due to the possibility of the reduction of structural sections and higher construction speed [26], in addition to the reduction in the overall cost of the structure [27].

In view of the large set of properties that can be influenced by the composition of high-performance concretes and the impossibility of maximizing them all at once, it is necessary to think about guided performance, that is, prioritize the most desired properties in the material for a given situation. Decision making in relation to the proportions and 
types of materials available can involve a series of requirements that significantly impact the overall performance of the concrete.

The Analytic Hierarchy Process (AHP) seeks the selection of alternatives in a process considering different evaluation criteria [28]. Developed by Thomas L. Saaty in the 1970s, the method helps to organize a structured and rational network for a decision problem [29]. Handfield et al. [30] highlight that the main advantage of AHP is in treating the decision as a global system, synthesizing all available information and thus making previously complex decision processes more rational. The authors add that without using a decision support methodology, the decision maker does not end up adequately considering all the factors involved, their weights and relative interactions.

In the field of Civil Engineering, the potential of hierarchical analysis has been increasingly explored, so it is possible to cite examples of studies that used it as a decision tool, such as: 1 - Pan [31], in the choice of bridge construction methods; 2 - Lai et al. [32], in the public works project; 3 - Perelles et al. [33] for the selection of structural reinforcement systems; 4 - Pretto et al. [34] for the selection of vertical barrier systems to contain groundwater contaminants; 5 - Grunberg et al. [35] for the comparison among environmentally certified sealing systems for homes; 6 - Pereira et al. [36] and Mattana et al. [37] in studies in the area of recycling construction waste for making concrete and mortar.

In view of the entire context presented, the present work aims to apply the Analytic Hierarchy Process in the choice of concretes for high-performance applications, considering 3 scenarios of practical application. The aim is to contribute to the development of a systemic selection process of concretes considering the specific conditions of each use.

\section{METHOD}

The methodology used in the present study consisted of applying the Analytic Hierarchy Process based on the results of an experimental study developed by Rebmann [38]. This author evaluated durability parameters and mechanical properties of concretes with high strength and low content Portland cement from mixtures composed of different cement types and contents. It is worth mentioning that despite the use of the term HSC (High-strength concrete) in the work developed by Rebmann [38], in this present study the term HPC (High-performance concrete) will be used since it is intended to encompass other properties of the concrete besides the compressive strength. In addition, to form the AHP criteria, the environmental performance represented by the $\mathrm{CO}_{2}$ emission and the economic attractiveness (cost per $\mathrm{m}^{3}$ of concrete) were also considered for the mixtures under study.

CP V-ARI and CP III-40-RS cements were used, as well as three different cement contents, two being of low content and one of normal content. To define these contents, the following premises were adopted:

a) For the reference mixtures (normal cement content), it was decided to follow the recommendation of maximum durability of the Brazilian standard NBR 12655 [39], that is, environmental aggressiveness class IV. For this class, the standard specifies a cement content of at least $360 \mathrm{~kg} / \mathrm{m}^{3}$, in addition to a water/cement ratio of not more than 0.45 and compressive strength of at least $40 \mathrm{MPa}$ at 28 days.

b) For the low cement content mixtures, the following were adopted: a content of $280 \mathrm{~kg} / \mathrm{m}^{3}$, which is equivalent to that required for environmental aggressiveness class II; and a content of $200 \mathrm{~kg} / \mathrm{m}^{3}$, which is below the aforementioned normative recommendations.

In the composition of the reference mixtures, only one granulometry of each aggregate (fine and coarse) was used. On the other hand, for the low content mixtures, there was a combination of three sands and two gravels, as well as the use of mineral additions. This granulometric diversity aimed to obtain better packing both in the granular skeleton of aggregates and in the cementitious matrix.

The cone slump specified for the reference concretes was $8 \pm 2 \mathrm{~cm}$. On the other hand, a superplasticizer additive was used for the other mixtures, which allowed the increase of fluidity and the obtaining of slumps greater than $17 \mathrm{~cm}$.

The characteristics adopted after the dosage tests and the respective nomenclatures for each mixture are shown in Table 1.

Table 1. Characteristics and nomenclature of the mixtures evaluated. Adapted from Campos et al. [17].

\begin{tabular}{ccccccc}
\hline \multirow{2}{*}{ Material parameter } & \multicolumn{5}{c}{ Mixture nomenclature } \\
\cline { 2 - 7 } Type of cement & VR4 & IIIR4 & V280 & III280 & V200 & III210 \\
\hline \multirow{2}{*}{ Cement consumption $\left(\mathrm{kg} / \mathrm{m}^{3}\right)$} & CP V & CP III & CP V & CP III & CP V & CP III \\
\cline { 2 - 7 } & ARI & $\mathbf{4 0 - R S}$ & ARI & $\mathbf{4 0 - R S}$ & ARI & 40-RS \\
\hline
\end{tabular}


Table 1. Continued..

\begin{tabular}{ccccccc}
\hline Material parameter & & \multicolumn{3}{c}{ Mixture nomenclature } \\
\cline { 2 - 7 } & VR4 & IIIR4 & V280 & III280 & V200 & III210 \\
\hline Active silica $\left(\mathrm{kg} / \mathrm{m}^{3}\right)$ & - & - & 16.9 & 17.4 & 12.1 & 13.1 \\
\hline Metakaolin $\left(\mathrm{kg} / \mathrm{m}^{3}\right)$ & - & - & 6.5 & 6.7 & 4.6 & 5.0 \\
\hline Filler $($ ground silica $)\left(\mathrm{kg} / \mathrm{m}^{3}\right)$ & - & - & 51.6 & 51.2 & 53 & 52.7 \\
\hline Sand $1\left(\mathrm{~kg} / \mathrm{m}^{3}\right)$ & 685 & 676 & 470.8 & 466.9 & 483.4 & 480.6 \\
\hline Sand $2\left(\mathrm{~kg} / \mathrm{m}^{3}\right)$ & - & - & 313.9 & 311.3 & 322.3 & 320.4 \\
\hline Sand $3\left(\mathrm{~kg} / \mathrm{m}^{3}\right)$ & - & - & 196.2 & 194.6 & 201.4 & 200.3 \\
\hline Pebble $\left(\mathrm{kg} / \mathrm{m}^{3}\right)$ & - & - & 413 & 409.6 & 424.0 & 421.6 \\
\hline Gravel $1\left(\mathrm{~kg} / \mathrm{m}^{3}\right)$ & 1.111 & 1.114 & 619.5 & 614.4 & 636.0 & 632.4 \\
\hline Mixing water $\left(\mathrm{kg} / \mathrm{m}^{3}\right)$ & 191.7 & 190.0 & 128.3 & 128.9 & 130.5 & 130.7 \\
\hline Superplasticizer $\left(\mathrm{kg} / \mathrm{m}^{3}\right)$ & - & - & 6.04 & 5.99 & 4.32 & 4.52 \\
\hline Water/binder ratio* & 0.451 & 0.434 & 0.436 & 0.442 & 0.617 & 0.590 \\
\hline Mortar content $(\%)$ & 50 & 50 & 56.4 & 56.4 & 54.6 & 54.8 \\
\hline Total binders $\left(\mathrm{kg} / \mathrm{m}^{3}\right)$ & 426.1 & 437.4 & 302.0 & 299.6 & 216.0 \\
\hline
\end{tabular}

* this value refers to the ratio (mixing water + additive water)/total binders

Table 2 shows the results of mechanical properties, durability and cost of concretes obtained by Rebmann [38], as well as the $\mathrm{CO}_{2}$ emission content calculated by the authors. The tests performed by Rebmann [38] are briefly described below.

Table 2. Database obtained from the experiments [17].

\begin{tabular}{|c|c|c|c|c|c|c|}
\hline \multirow{2}{*}{ Analysis parameter } & \multicolumn{6}{|c|}{ Mixture nomenclature } \\
\hline & VR4 & IIIR4 & V280 & III280 & V200 & III210 \\
\hline Compressive strength $^{(1)}-28$ days (MPa) & 40.7 & 30.0 & 67.9 & 55.4 & 51.9 & 34.5 \\
\hline Modulus of elasticity ${ }^{(1)}-28$ days (GPa) & 42.1 & 36.1 & 51.4 & 50.8 & 49.0 & 43.5 \\
\hline Flexural tensile strength ${ }^{(2)}(\mathrm{MPa})$ & 4.5 & 4.7 & 8.3 & 7.2 & 6.2 & 5.1 \\
\hline Water absorption $^{(1)(3)}-63$ days $(\%)$ & 5.5 & 5.9 & 3.2 & 2.5 & 3.8 & 3.8 \\
\hline Abrasion $^{(4)} 1000 \mathrm{~m}(\mathrm{~mm})$ & 1.0 & 1.6 & 1.2 & 1.4 & 1.5 & 1.6 \\
\hline Permeability $^{(5)}(10-12 \mathrm{~m} / \mathrm{s})$ & 2.5 & 3.1 & 1.4 & 2.4 & 2.7 & 4.7 \\
\hline Carbonation $^{(2)}-96$ days $(\mathrm{mm})$ & $0(8)$ & 14.6 & 1.7 & 9.8 & 11.1 & 22.3 \\
\hline Corrosion potential $^{(6)}-17$ cycles $(\mathrm{mV})$ & -530 & -460 & -320 & -440 & -230 & -590 \\
\hline $\operatorname{Cost}\left(\mathrm{R} \$ / \mathrm{m}^{3}\right)$ & 249.14 & 253.35 & 330.33 & 328.20 & 277.21 & 283.57 \\
\hline $\mathrm{CO}_{2}$ emission $^{(7)}(\mathrm{kg})$ & 348 & 184 & 228 & 116 & 163 & 88 \\
\hline
\end{tabular}

(1) Test on 10x20cm cylindrical specimens according to NBR 5739 [40]. (2) Test on 10x10x50cm prismatic specimens according to NBR 12142 [41]. ${ }^{(3)}$ Test according to NBR 9778 [42]. ${ }^{(4)}$ Test according to NBR 12042 [43]. ${ }^{(5)}$ Tests based on the German Water Permeability Test (GWT). ${ }^{(6)}$ Test according to ASTM

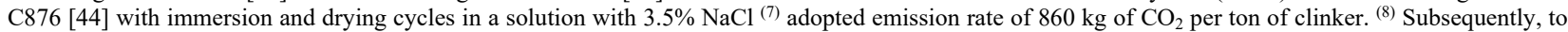
allow the calculations to be carried out, this value will be admitted as $1 \mathrm{~mm}$, remaining as the lowest value.

\subsection{Test methods}

In mechanical terms, the following were evaluated: compressive strength in $10 \mathrm{~cm} \times 20 \mathrm{~cm}$ cylindrical specimens, according to the specifications of NBR 5739:2007 [40]; static modulus of elasticity in $10 \mathrm{~cm} \times 20 \mathrm{~cm}$ cylindrical specimens, according to the specifications of NBR 8522:2008 [45]; and flexural tensile strength at four points (Figure 1a) in $10 \mathrm{~cm} \times 10 \mathrm{~cm} \times 50 \mathrm{~cm}$ prismatic specimens, according to the specifications of NBR 12142:2010 [41]. Although other ages were assessed in the original study, in this article only the age of 28 days was considered.

In order to assess durability, different aspects of aggression to concrete were considered by which a good part of the degradation in concrete occurs, with an emphasis on porosity and permeability. Water absorption was evaluated by immersion [42] in $10 \mathrm{~cm} \times 20 \mathrm{~cm}$ cylindrical specimens cast in PVC molds without using a release agent so as not to cause surface waterproofing. Water permeability was determined by the German Water Permeability Test (GWT) (Figure 11 and $1 \mathrm{k}$ ). This rapid test is recommended for field evaluations in order to determine the permeability of existing structures without the need for sample extraction. In this test, the apparatus, which consists of a pressure 
chamber and devices to record and regulate the water pressure, is installed on the specimen. The permeability coefficient was determined, according to Darcy's law, from the water flow that permeates the specimen at a given pressure level (3 bar) after the establishment of a continuous flow.

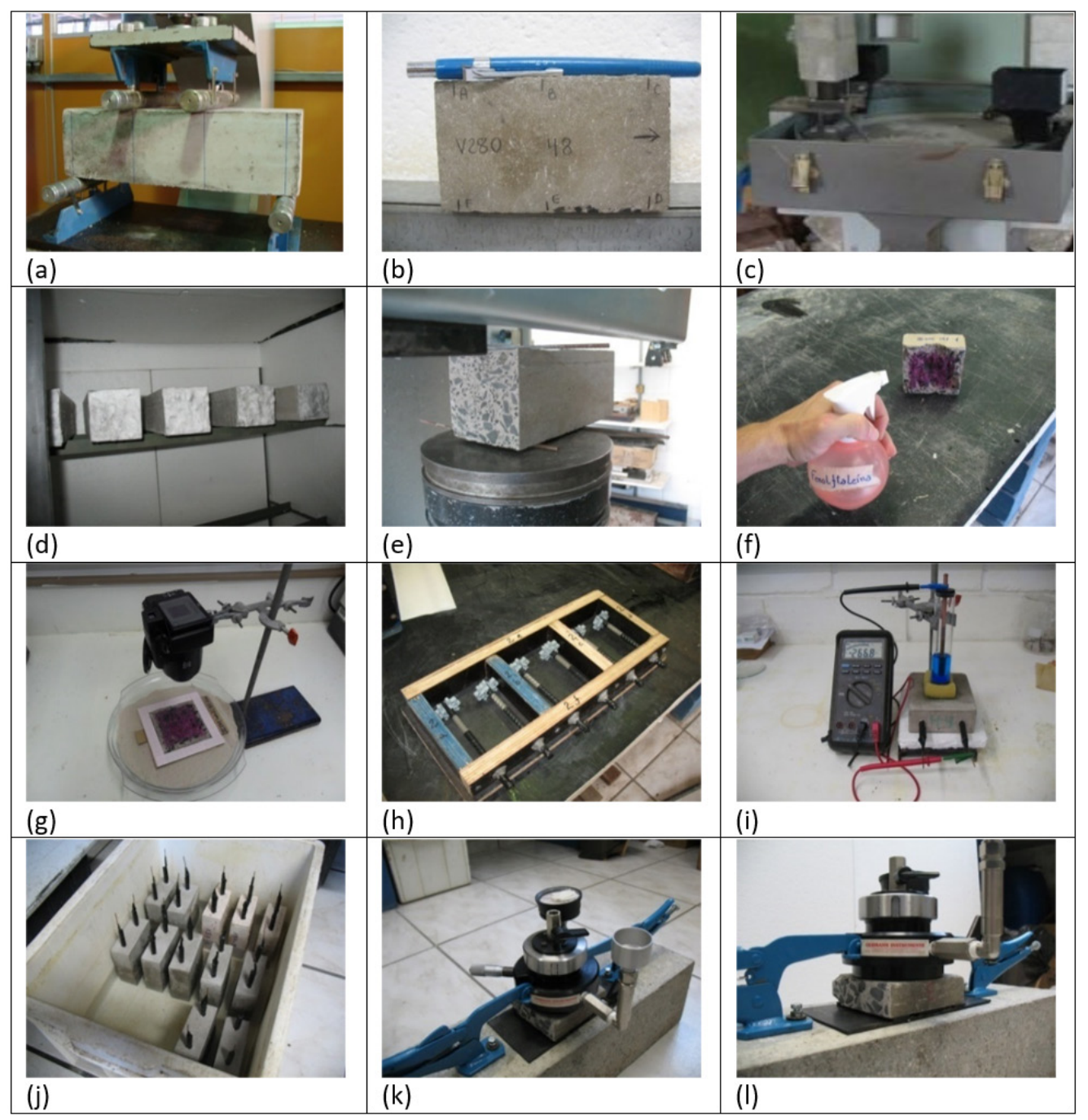

Figure 1. Illustration of details of the tests performed: (a) Four-point flexural test; (b) specimen used in the abrasion test; (c) Dorry Abrasion Machine; (d) prismatic specimens with ends sealed with wax, arranged inside the accelerated carbonation chamber; (e) slice extraction by compression (f) spraying the phenolphthalein solution on the newly fractured surface; (g) image acquisition of carbonated surface; (h) mold and reinforcement used in making specimens to test for corrosion potential; (i) assembly of the corrosion potential test, with a copper/copper sulphate electrode placed on the specimen and connected by means of a voltmeter to the working electrodes/steel bars; (j) partial immersion in sodium chloride solution to accelerate the corrosion process; ( $\mathrm{k}$ and $\mathrm{l}$ ) assembly of the German Water Permeability Test apparatus to assess water permeability.

Using an accelerated test, carbonation was evaluated in $10 \mathrm{~cm} \times 10 \mathrm{~cm} \times 50 \mathrm{~cm}$ prismatic specimens, molded without the use of a release agent so as not to cause waterproofing of the surface. After curing in a humidity chamber for 28 days, they were stored in the humidity of the accelerated test $(65 \%)$ until mass constancy. This occurred at the age of 91 days. From this age, the specimens were kept in a carbonation chamber (Figure 1d) with a controlled temperature $\left(25^{\circ} \mathrm{C}\right)$ and $\mathrm{CO}_{2}$ concentration $(5 \%)$. The carbonation depth was evaluated at the ages of $6,14,28,56$ and 96 days. At each of these ages, a slice of the specimen was extracted by transversal compression (Figure 1e) and sprinkled with phenolphthalein solution as a $\mathrm{pH}$ indicator (Figure 1f). The minimum, average and maximum depths 
were determined with the aid of image analysis (Figure 1i). In this article, the value of the average depth at 96 days was considered as an indicator.

Abrasion was evaluated on Dorry Abrasion Machine equipment (Figure $1 \mathrm{~b}$ and 1c), and the test conditions matched the specifications of NBR 12042:1992 [43], using standard sand (IPT 50) as abrasive material. Abrasion was determined after 500 and 1,000 meters, and in this article the value for 1000 meters was analyzed.

In relation to the corrosion process, the corrosion potential was evaluated according to the procedure of ASTM C876:2009 [44]. This test measures the potential difference developed between a standard electrode (copper/copper sulfate electrode was used), positioned on the surface of the specimen, and steel bars inserted into the concrete. Concrete specimens of $5 \mathrm{~cm} \times 10 \mathrm{~cm} \times 10 \mathrm{~cm}$ were molded with 2 embedded $8 \mathrm{~mm}$ steel bars. These bars were previously cleaned to eliminate oxidation and then partially isolated in order to delimit a controlled area inside the specimen susceptible to the corrosion process (Figure 1h). After initial curing in a humidity chamber, the specimens were subjected to four-day cycles of drying in a heating chamber at $50^{\circ} \mathrm{C}$, followed by three days of partial immersion in saline solution of $3.5 \% \mathrm{NaCl}$ by mass (Figure 1j). Over 4 months, the difference in electrical potential between the steel bar and the standard electrode was determined at the end of the immersion steps (Figure 1i). The final value after 17 cycles was considered in this article.

\subsection{Test methods Hierarchical analysis for decision making}

Based on the available data, a hierarchy structure was built as shown in Figure 2.

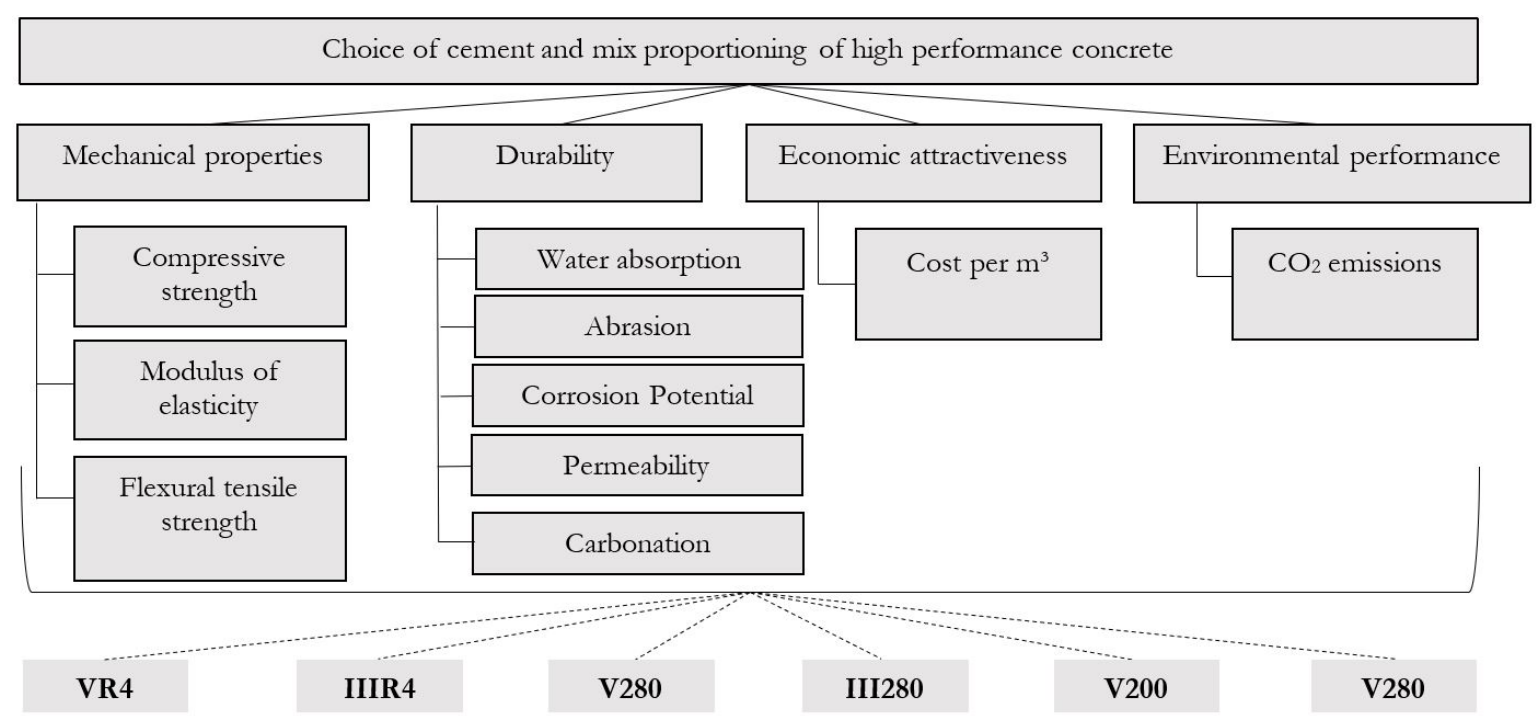

Figure 2. Criteria and sub-criteria used.

In order to allow decision making, it was also necessary to establish weights for each of the criteria and sub-criteria, thus reducing the subjectivity of the decision, as explained by Gregório [46]. However, this fact requires that the analyzers have knowledge and experience regarding the topic to be analyzed, since the main way to assign the weights is through previous knowledge or convictions.

It is a fact that the definition of a material's composition is linked to the context to which it will be applied. Therefore, in order to evaluate the application of the Analytic Hierarchy Process, hypothetical scenarios were established to guide the process of assigning weights based on their specific demands and limitations.

In this work, hierarchical analysis was applied to determine the most satisfactory material composition (mixture and type of cement) for three hypothetical applications:

a) Scenario 1: Concrete to be applied to an industrial floor of a chemical factory;

b) Scenario 2: Structural concrete to be applied to a thirty-story building in an urban, non-coastal region;

c) Scenario 3: High-volume foundation block of a green building. 
The choice of these three scenarios sought to consider different performance criteria. In the first scenario, durability represents abrasion and permeability as decisive factors. In the second scenario, mechanical resistance acts with greater importance. In the third, the environmental issue is more prevalent.

Based on these three scenarios as well as the criteria and sub-criteria shown in Figure 2, their weights were determined, as shown in Tables 3 to 9. Table 3 shows the weight scale adopted and the logic of filling out the decision matrix. The decision matrices were then filled out following the logic presented in Table 4. Initially, weights were assigned between criteria A-B, B-C and C-D and from these values the other matrix weights were calculated (Table 4).

Table 3. Judgment scale and logic of filling out the decision matrix.

\begin{tabular}{|c|c|c|c|c|}
\hline \multicolumn{4}{|l|}{ Judgment scale } & Weight \\
\hline \multicolumn{4}{|c|}{$\mathrm{A}$ is equally as important as B } & 1.00 \\
\hline \multicolumn{4}{|c|}{ A is moderately more (less) important than B } & $2.00(0.5)$ \\
\hline \multicolumn{4}{|c|}{ A is extremely more (less) important than B } & $3.00(0.33)$ \\
\hline Analysis parameter & $\mathbf{A}$ & B & $\mathbf{C}$ & D \\
\hline $\mathrm{A}$ & 1.00 & $\mathrm{a}$ & $\mathrm{a} \times \mathrm{b}$ & $\mathrm{a} \times \mathrm{b} \times \mathrm{c}$ \\
\hline B & $1 / \mathrm{a}$ & 1.00 & $\mathrm{~b}$ & $\mathrm{~b} \times \mathrm{c}$ \\
\hline $\mathrm{C}$ & $1 /(a \times b)$ & $1 / \mathrm{b}$ & 1.00 & $\mathrm{c}$ \\
\hline $\mathrm{D}$ & $1 /(a \times b \times c)$ & $1 /(b \times c)$ & $1 / \mathrm{c}$ & 1.00 \\
\hline
\end{tabular}

The decision of the weights for Scenario 1 (Table 4) took into account the following considerations:

a) The durability of an industrial floor is of greater relevance than factors such as cost and mechanical resistance, considering that a possible repair on this floor would cause a major disturbance to the factory's functionality.

b) Within the criterion of durability, permeability and abrasion resistance are the most important sub-criteria. The first is due to the fact that the factory works with chemical products and excessive permeability could compromise both the microstructure of the concrete itself and the quality of the soil under the floor. Abrasion resistance, on the other hand, would cause premature wear of the floor, in addition to the release of powdery material that could also compromise the factory operability.

c) Within the criterion of mechanical properties, the flexural tensile strength was considered the most important subcriterion due to the forces that occur on these slabs.

Table 4. Decision matrix of criteria, mechanical properties sub-criteria and durability sub-criteria (Scenario 1 - Industrial floor).

\begin{tabular}{|c|c|c|c|c|}
\hline Analysis parameter (Main criteria) & 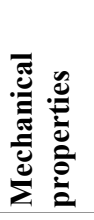 & 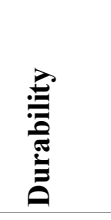 & 号 & 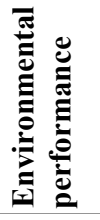 \\
\hline Mechanical properties & 1.0 & 0.33 & 1.0 & 2.0 \\
\hline Durability & 3.0 & 1.0 & 3.0 & 6.0 \\
\hline Economic attractiveness & 1.0 & 0.33 & 1.0 & 2.0 \\
\hline Environmental performance & 0.5 & 0.17 & 0.50 & 1.0 \\
\hline \multicolumn{2}{|c|}{ Analysis parameter (Mechanical properties sub-criteria) } & 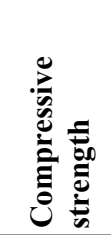 & 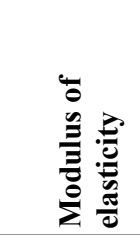 & 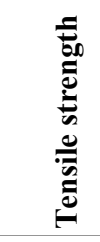 \\
\hline \multicolumn{2}{|l|}{ Compressive strength } & 1.0 & 2.0 & 0.67 \\
\hline \multicolumn{2}{|l|}{ Modulus of elasticity } & 0.5 & 1.0 & 0.33 \\
\hline \multicolumn{2}{|l|}{ Tensile strength } & 1.5 & 3.0 & 1.0 \\
\hline
\end{tabular}


Table 4. Continued...

\begin{tabular}{|c|c|c|c|c|c|}
\hline Analysis parameter (Durability sub-criteria) & 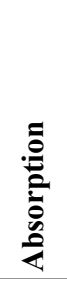 & 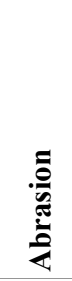 & 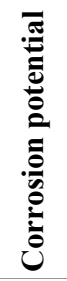 & 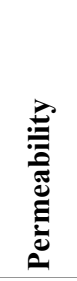 & Uี \\
\hline Absorption & 1.0 & 0.33 & 1.0 & 0.33 & 1.0 \\
\hline Abrasion & 3.0 & 1.0 & 3.0 & 1.0 & 3.0 \\
\hline Corrosion potential & 1.0 & 0.33 & 1.0 & 0.33 & 1.0 \\
\hline Permeability & 3.0 & 1.0 & 3.0 & 1.0 & 3.0 \\
\hline Carbonation & 1.0 & 0.33 & 1.0 & 0.33 & 1.0 \\
\hline
\end{tabular}

For scenario 2, there was a significant change in the weights (Table 5) due to the following arguments:

a) Mechanical performance has priority over durability because it is a structural element that is related to the shortterm safety of the people who use this building. Durability, on the other hand, ensures that this use is possible for a maximum period of time. However, without adequate mechanical resistance, durability is also compromised.

b) Within the durability criteria, the sub-criteria related to corrosion potential and carbonation are more relevant in this scenario, since corrosion of reinforcement by carbonation is one of the most critical problems with regard to the durability of a building located in an urban and non-coastal region.

Table 5. Decision matrix of criteria, mechanical properties sub-criteria and durability sub-criteria (Scenario 2 - building structure).

\begin{tabular}{|c|c|c|c|c|c|c|}
\hline Analysis parameter (Main criteria) & 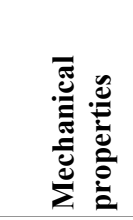 & & 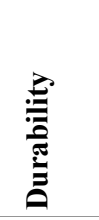 & \multicolumn{2}{|c|}{ } & 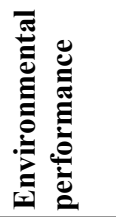 \\
\hline Mechanical properties & 1.0 & & 2.0 & \multicolumn{2}{|c|}{4.0} & 8.0 \\
\hline Durability & 0.5 & & 1.0 & \multicolumn{2}{|c|}{2.0} & 4.0 \\
\hline Economic attractiveness & 0.25 & & 0.5 & \multicolumn{2}{|c|}{1.0} & 2.0 \\
\hline Environmental performance & 0.13 & & 0.25 & \multicolumn{2}{|c|}{0.5} & 1.0 \\
\hline \multicolumn{2}{|c|}{ Analysis parameter (Mechanical properties sub-criteria) } & & 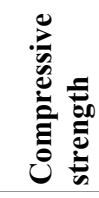 & \multicolumn{2}{|c|}{ 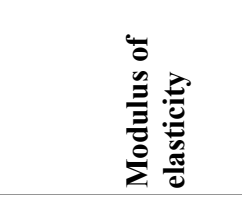 } & 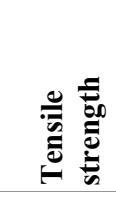 \\
\hline \multicolumn{2}{|l|}{ Compressive strength } & \multicolumn{2}{|r|}{1.0} & \multicolumn{2}{|c|}{2.0} & 4.0 \\
\hline \multicolumn{2}{|l|}{ Modulus of elasticity } & \multicolumn{2}{|r|}{0.5} & \multicolumn{2}{|c|}{1.0} & 2.0 \\
\hline \multicolumn{2}{|l|}{ Tensile strength } & \multicolumn{2}{|r|}{0.25} & \multicolumn{2}{|c|}{0.5} & 1.0 \\
\hline Analysis parameter (Durability sub-criteria) & 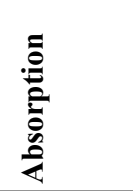 & 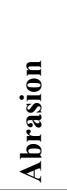 & & & 尝 & نี \\
\hline Absorption & 1.0 & 1.0 & & 0.33 & 1.0 & 0.33 \\
\hline Abrasion & 1.0 & 1.0 & & 0.33 & 1.0 & 0.33 \\
\hline Corrosion Potential & 3.0 & 3.0 & & 1.0 & 3.0 & 1.0 \\
\hline Permeability & 1.0 & 1.0 & & 0.33 & 1.0 & 0.33 \\
\hline Carbonation & 3.0 & 3.0 & & 1.0 & 3.0 & 1.0 \\
\hline
\end{tabular}


For scenario 3 (Table 6), the following questions were taken into account:

a) Environmental performance has priority over other criteria, followed by durability, mechanical properties and lastly, economic attractiveness.

b) Within the durability sub-criteria, corrosion potential and permeability are more relevant in this scenario, since these are the main ones that could affect the service life of a foundation block.

c) In the sub-criterion of mechanical properties, compressive strength is the most relevant given the mechanical functioning of a foundation block (compression rods).

Table 6. Decision matrix of criteria, mechanical properties sub-criteria and durability sub-criteria (Scenario 3 - foundation block).

\begin{tabular}{|c|c|c|c|c|c|c|}
\hline Analysis parameter (Main criteria) & 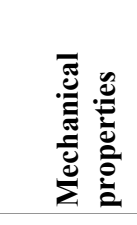 & & 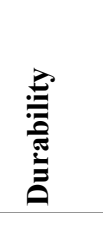 & \multicolumn{2}{|c|}{ 总 } & 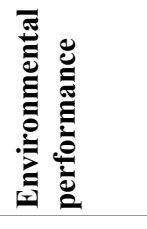 \\
\hline Mechanical properties & 1.00 & & 0.50 & \multicolumn{2}{|c|}{1.00} & 0.33 \\
\hline Durability & 2.00 & & 1.00 & \multicolumn{2}{|c|}{2.00} & 0.66 \\
\hline Economic attractiveness & 1.00 & & 0.50 & \multicolumn{2}{|c|}{1.00} & 0.33 \\
\hline Environmental performance & 3.03 & & 1.50 & \multicolumn{2}{|c|}{3.00} & 1.00 \\
\hline \multicolumn{2}{|c|}{ Analysis parameter (Mechanical properties sub-criteria) } & & 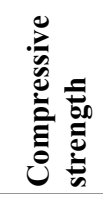 & \multicolumn{2}{|c|}{ 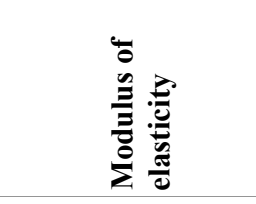 } & 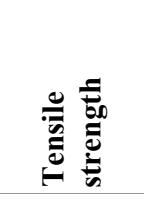 \\
\hline \multicolumn{2}{|l|}{ Compressive strength } & \multicolumn{2}{|r|}{1.0} & \multicolumn{2}{|c|}{2.0} & 2.0 \\
\hline \multicolumn{2}{|l|}{ Modulus of elasticity } & \multicolumn{2}{|r|}{0.5} & \multicolumn{2}{|c|}{1.0} & 1.0 \\
\hline \multicolumn{2}{|l|}{ Tensile strength } & \multicolumn{2}{|r|}{0.5} & \multicolumn{2}{|c|}{1.0} & 1.0 \\
\hline Analysis parameter (Durability sub-criteria) & 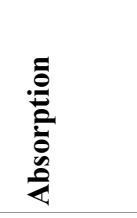 & 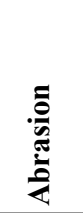 & & 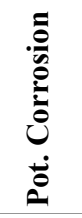 & 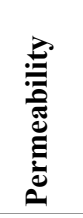 & 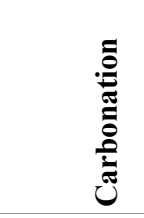 \\
\hline Absorption & 1.00 & 2.00 & & 0.66 & 1.32 & 2.64 \\
\hline Abrasion & 0.50 & 1.00 & & 0.33 & 0.66 & 1.32 \\
\hline Corrosion Potential & 1.52 & 3.03 & & 1.00 & 2.00 & 4.00 \\
\hline Permeability & 0.76 & 1.52 & & 0.50 & 1.00 & 2.00 \\
\hline Carbonation & 0.38 & 0.76 & & 0.25 & 0.50 & 1.00 \\
\hline
\end{tabular}

\section{RESULTS AND DISCUSSION}

Subsequent to the assignment of weights, the results must be normalized in order to be able to apply the Analytic Hierarchy Process, seeking to place them in the same order of magnitude as well as following the same analysis logic. In other words, the greater the value assigned to the parameter, the more satisfactory the evaluated item is. For this, working with the data in Table 2, an inversion was made of the results whose analysis parameters indicate that lower values would mean better performance, such as abrasion. Finally, the normalized data set was obtained from the process of dividing each result by the highest value obtained from the row, as shown in Table 7. 
Table 7. Standardized Data.

\begin{tabular}{ccccccc}
\hline & VR4 & IIIR4 & V280 & III280 & V200 & III210 \\
\hline Compressive strength - 28 days & 0.58 & 0.43 & 1.00 & 0.80 & 0.77 & 0.51 \\
\hline Modulus of elasticity - 28 days & 0.82 & 0.70 & 1.00 & 0.99 & 0.95 & 0.85 \\
\hline Flexural tensile strength & 0.54 & 0.57 & 1.00 & 0.87 & 0.75 & 0.61 \\
\hline Water absorption - 63 days & 0.45 & 0.42 & 0.78 & 1.00 & 0.66 & 0.66 \\
\hline Abrasion 1000 m & 1.00 & 0.63 & 0.83 & 0.71 & 0.67 & 0.63 \\
\hline Permeability & 0.56 & 0.45 & 1.00 & 0.58 & 0.52 & 0.30 \\
\hline Carbonation & 1.00 & 0.07 & 0.59 & 0.10 & 0.09 & 0.04 \\
\hline Corrosion potential - 17 cycles & 0.43 & 0.50 & 0.72 & 0.52 & 1.00 & 0.39 \\
\hline Cost & 1.00 & 0.98 & 0.75 & 0.76 & 0.90 & 0.88 \\
\hline $\mathrm{CO}_{2}$ Emission & 0.25 & 0.48 & 0.39 & 0.76 & 0.54 & 1.00 \\
\hline
\end{tabular}

Multiplying the normalized results presented in Table 7 by 100 and also by the relative importance presented in Table 4 (Scenario 1), Table 5 (Scenario 2) or Table 6 (Scenario 3), the performance index of each mixture was obtained for each sub-criterion of the 2 nd level analysis. Table 8 shows the performance indices for Scenario 1.

Table 8. Performance index of mechanical properties and durability (Scenario 1 - Industrial floor).

\begin{tabular}{ccccccccc}
\hline Mechanical properties & VR4 & IIIR4 & V280 & III280 & V200 & III210 \\
\cline { 1 - 5 } Compressive strength & 19.23 & 14.42 & 33.17 & 26.44 & 25.48 & 16.82 \\
\hline Modulus of elasticity & 13.58 & 11.65 & 16.58 & 16.39 & 15.81 & 14.03 \\
\hline Tensile strength & 27.24 & 28.46 & 50.25 & 43.59 & 37.54 & 30.88 \\
\hline Performance index & 60.05 & 54.52 & 100.00 & 86.42 & 78.82 & 61.73 \\
\hline Durability & VR4 & IIIR4 & V280 & III280 & V200 & III210 \\
\hline Water absorption & 4.98 & 4.65 & 8.56 & 10.96 & 7.21 & 7.21 \\
\hline Abrasion & 33.22 & 20.76 & 27.68 & 23.73 & 22.15 & 20.76 \\
\hline Corrosion potential & 4.81 & 5.54 & 7.96 & 5.79 & 11.07 & 4.32 \\
\hline Permeability & 18.79 & 15.15 & 33.56 & 19.57 & 17.40 & 10.00 \\
\hline Carbonation & 11.19 & 0.77 & 6.58 & 1.14 & 1.01 & 0.50 \\
\hline Performance index & 72.99 & 46.18 & 78.42 & 60.17 & 57.93 & 42.34 \\
\hline
\end{tabular}

With the performance indices of the second level calculated, the analysis of the first level is completed. For this, it is first necessary to again normalize the performance indices of the mechanical properties and durability criteria together with the results of cost and $\mathrm{CO}_{2}$ release (Table 9).

Table 9. Standardized data for 1st level analysis (Scenario 1 - Industrial floor).

\begin{tabular}{ccccccc}
\hline & VR4 & IIIR4 & V280 & III280 & V200 & III210 \\
\hline Mechanical properties & 0.60 & 0.55 & 1.00 & 0.86 & 0.79 & 0.62 \\
\hline Durability & 0.87 & 0.56 & 1.00 & 0.73 & 0.70 & 0.51 \\
\hline Economic attractiveness & 1.00 & 0.98 & 0.75 & 0.76 & 0.90 & 0.88 \\
\hline Environmental performance & 0.25 & 0.48 & 0.39 & 0.76 & 0.54 & 1.00 \\
\hline
\end{tabular}

Then, the values in Table 9 were multiplied by 100 and by the relative importance shown in Table 4 (Scenario 1). Finally, the results of each column were added to obtain the performance index for each mixture for this particular application (Table 10).

In the same way, it is also possible to find the performance indices for Scenario 2 (Table 11) and Scenario 3 (Table 12). 
Table 10. Final Performance Index (Scenario 1 - Industrial floor).

\begin{tabular}{cccccccc}
\hline & VR4 & IIIR4 & V280 & III280 & V200 & III210 \\
\hline Mechanical properties & 10.82 & 9.83 & 18.03 & 15.58 & 14.21 & 11.13 \\
\hline Durability & 47.28 & 30.36 & 54.64 & 39.65 & 38.12 & 27.72 \\
\hline Economic attractiveness & 18.21 & 17.91 & 13.74 & 13.83 & 16.37 & 16.00 \\
\hline Environmental performance & 2.30 & 4.36 & 3.52 & 6.91 & 4.92 & 9.11 \\
\hline Performance index & 78.63 & 62.46 & 89.93 & 75.97 & 73.62 & 63.97 \\
\hline
\end{tabular}

Table 11. Final Performance Index (Scenario 2 - Building structure).

\begin{tabular}{ccccccc}
\hline & VR4 & IIIR4 & V280 & III280 & V200 & III210 \\
\hline Mechanical properties & 34.28 & 28.27 & 53.33 & 45.96 & 43.63 & 33.04 \\
\hline Durability & 26.67 & 12.68 & 20.77 & 16.34 & 20.45 & 11.59 \\
\hline Economic attractiveness & 13.33 & 13.11 & 10.06 & 10.12 & 11.98 & 11.71 \\
\hline Environmental performance & 1.69 & 3.19 & 2.57 & 5.06 & 3.60 & 6.67 \\
\hline Performance index & 75.13 & 57.61 & 92.63 & 78.10 & 80.03 & 63.14 \\
\hline
\end{tabular}

Table 12. Final Performance Index (Scenario 3 - Foundation block).

\begin{tabular}{cccccccc}
\hline & VR4 & IIIR4 & V280 & III280 & V200 & III210 \\
\hline Mechanical properties & 8.96 & 7.60 & 14.22 & 12.26 & 11.50 & 8.80 \\
\hline Durability & 21.02 & 16.21 & 28.44 & 22.89 & 25.54 & 15.70 \\
\hline Economic attractiveness & 14.22 & 13.99 & 10.73 & 10.80 & 12.78 & 12.50 \\
\hline Environmental performance & 10.90 & 20.61 & 16.64 & 32.70 & 23.27 & 43.10 \\
\hline Performance index & 55.12 & 58.42 & 70.04 & 78.66 & 73.10 & 80.11 \\
\hline
\end{tabular}

From the results obtained, it was found that the V280 mixture presented the highest final performance index for both hypothetical scenarios 1 and 2, therefore being the best choice for these situations. This may be mainly related to the fact that the V280 mixture performed better in most of the criteria considered, except for the parameters of abrasion, absorption, corrosion potential and $\mathrm{CO}_{2}$ emission, as shown in Table 12. Therefore, this mixture was not the best in Scenario 3, but rather was the mixture III 210 .

It can also be noted that, despite not being the mixture with the best abrasion performance, which is one of the main requirements for floors, V280 was still the mixture with the best indication for scenario 1 (industrial floor) due to its better performance in the other criteria.

The mixture that presented the worst performance in scenarios 1 and 2 was also the same, IIIR4. This mixture, unlike the V280, presented the most unsatisfactory performance in practically all the analyzed criteria. Thus, it is observed that just meeting regulatory requirements (such as NBR 6118 [2] and NBR 12655 [39]) is not enough to choose the best solution.

The mixtures with CPV-ARI cement presented advantages in scenarios 1 and 2 compared to the mixtures with CPIII cement. The opposite occurred in Scenario 3, in which there was an advantage for the mixtures with CPIII cement. In addition, the mixtures with low cement content were also shown to be superior to the reference mixtures in all analyzed scenarios. Such considerations confirm the conclusions obtained by Rebmann [38] that it is possible to produce adequate concretes that meet design, cost and sustainability requirements, even though they use a cement content lower than that specified in NBR 6118 [2] and NBR 12655 [39].

As can be seen in Figures 3 to 5, the V280 mixture presented a better performance regarding mechanical property and durability criteria. Only in one scenario, in which environmental or economic performance was the most relevant variable (Scenario 3), was this mixture not the best choice. 


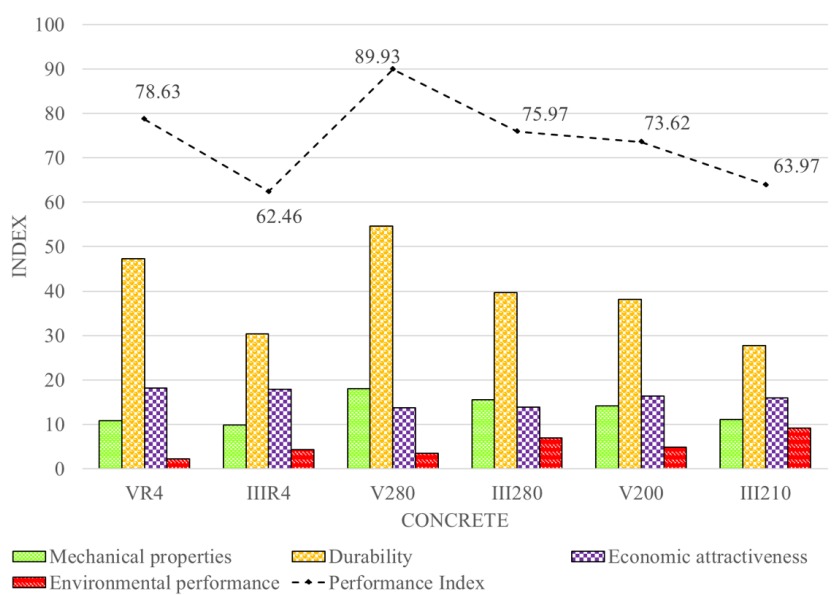

Figure 3. Partial indices of criteria and final performance index - Scenario 1 (industrial floor).

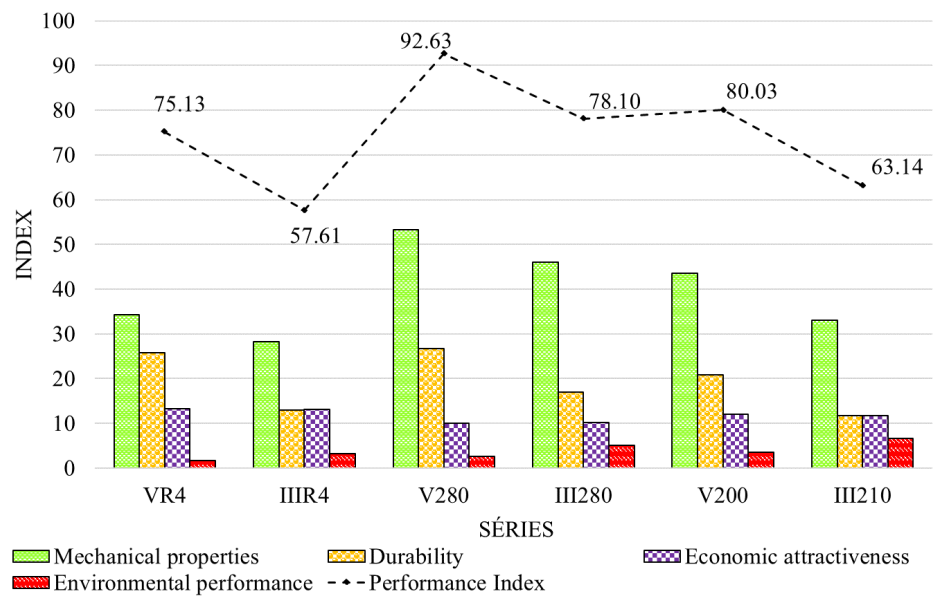

Figure 4. Partial indices of criteria and final performance index - Scenario 2 (building structure).

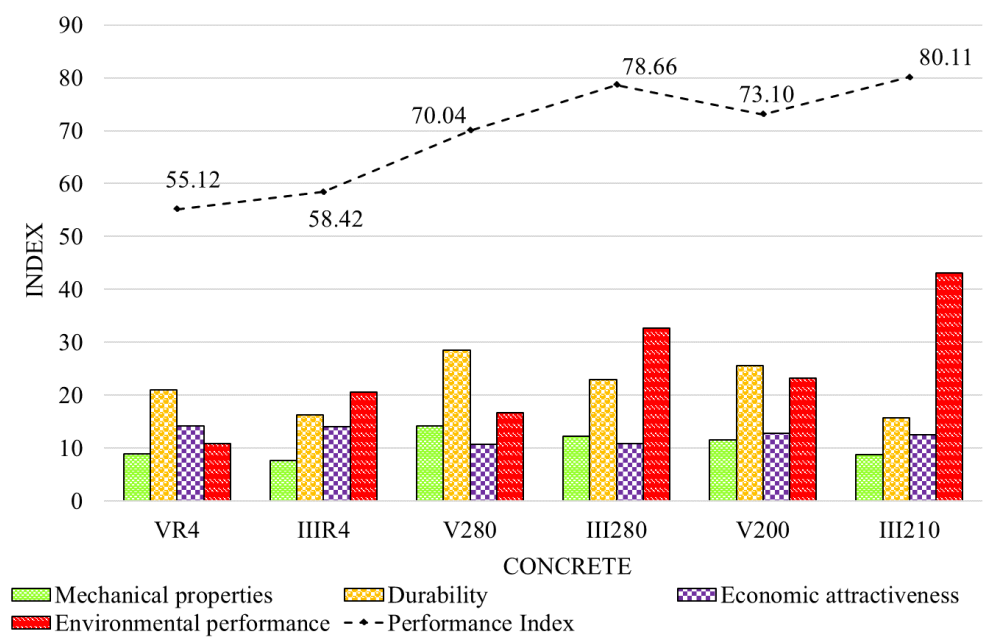

Figure 5. Partial indices of criteria and final performance index - Scenario 3 (foundation block). 


\section{CONCLUSIONS}

The basic premise of this work was the application of the Analytic Hierarchy Process (AHP) as a tool for choosing the composition of high-performance concretes for three practical application scenarios: (scenario 1) industrial floor of a chemical factory; (scenario 2) reinforced concrete structure of a thirty-story building in an urban, non-coastal region and (scenario 3) high-volume foundation block for a green building.

The following conclusions were drawn from this work:

- The results showed that, in scenarios 1 and 2, the concrete composed of CPV-ARI cement with a content of about $280 \mathrm{~kg} / \mathrm{m}^{3}$ (V280) was considered the alternative that best met the choice criteria. The use of CPV-ARI cement in general proved to be superior to CPIII cement for these first two scenarios analyzed.

- The differences between the requirements of the studied scenarios 1 and 2 resulted in only one change in the choice order of the mixtures. In scenario 1 (the industrial floor), the second choice option would be the concrete with a content of $426.1 \mathrm{~kg} / \mathrm{m}^{3}$ of CPV-ARI cement and the fourth option would be the concrete with a content of $200 \mathrm{~kg} / \mathrm{m}^{3}$ of CPV-ARI cement. In scenario 2 (the building structure), this order is reversed.

- Analyzing scenario 3, the mix with $210 \mathrm{~kg} / \mathrm{m}^{3}$ of CPIII cement was the best option.

- Although AHP has proven to be an accessible and easy to apply tool, it became evident that its effectiveness depends on a good structuring of the problem and weight system. In this way, AHP can be considered an instrument that can assist with problems systemically and thus contribute with information that feeds the decision-making process.

- This type of research can serve as support for the future development of artificial intelligence systems in order to systematize and implement means of rational decision making that can be conducted by computers. In this way, the main focus of this work should be given to the process that is being proposed and exemplified in order to glimpse its potential for use in the systemic choice of concretes more suitable for different applications.

\section{ACKNOWLEDGEMENTS}

The authors would like to thank the support of the Graduate Program in Civil Construction Engineering (PPGECC) and the Civil Engineering Studies Center (CESEC) of the Federal University of Paraná (UFPR), in addition to the São Carlos School of Engineering (EESC) and the Polytechnic School (POLI), both from the University of São Paulo (USP).

\section{REFERENCES}

[1] J. R. Clifton, "Predicting the service life of concrete," ACI Mater. J., vol. 90, no. 6, pp. 611-617, 1993.

[2] Associação Brasileira de Normas Técnicas, Projeto de Estruturas de Concreto, NBR 6118, 2014.

[3] M. H. F. Medeiros, J. J. D. O. Andrade, and P. Helene, "Durabilidade e vida útil das estruturas de concreto," in Concreto: Ciência e Tecnologia, G. C. Isaia, Ed., São Paulo: IBRACON, 2011, pp. 887-902.

[4] P. C. Aitcin, "The durability characteristics of high performance concrete: a review," Cement Concr. Compos., vol. 25, no. 4-5, pp. 409-420, 2003.

[5] L. Sorelli, G. Constantinides, F. J. Ulm, and F. Toutlemonde, "The nano-mechanical signature of ultra high performance concrete by statistical nanoindentation techniques," Cement Concr. Res., vol. 38, no. 12, pp. 1447-1456, 2008.

[6] G. C. Cordeiro, R. D. Toledo Fo., and E. M. R. Fairbairn, "Use of ultrafine rice husk ash with high-carbon content as pozzolan in high performance concrete," Mater. Struct., vol. 42, no. 7, pp. 983-992, 2009.

[7] H. Shi, B. Xu, and X. Zhou, "Influence of mineral admixtures on compressive strength, gas permeability and carbonation of high performance concrete," Constr. Build. Mater., vol. 23, no. 5, pp. 1980-1985, 2009.

[8] S. Zhutovsky and K. Kovler, "Effect of internal curing on durability-related properties of high performance concrete," Cement Concr. Res., vol. 42, no. 1, pp. 20-26, 2012.

[9] D. Sirtoli, M. Wyrzykowski, P. Riva, S. Tortelli, M. Marchi, and P. Lura, "Shrinkage and creep of high-performance concrete based on calcium sulfoaluminate cement," Cement Concr. Compos., vol. 98, pp. 61-73, 2019.

[10] D. Shen, X. Liu, X. Zeng, X. Zhao, and G. Jiang, "Effect of polypropylene plastic fibers length on cracking resistance of high performance concrete at early age," Constr. Build. Mater., vol. 244, pp. 117874, 2020.

[11] T. R. P. Jucá, F. A. Teixeira, C. H. A. F. Pereira, L. E. Guimarães, and E. J. P. Figueiredo, "Influência das adições minerais na corrosão de armaduras induzidas por cloretos," in An. $43^{\circ}$ Congr. Bras. Concr., Foz do Iguaçu, 2001, pp. 1-15.

[12] K. Celik et al., "High-volume natural volcanic pozzolan and limestone powder as partial replacements for Portland cement in selfcompacting and sustainable concrete," Cement Concr. Compos., vol. 45, pp. 136-147, 2014. 
[13] H. El-Chabib and A. Syed, "Properties of self-consolidating concrete made with high volumes of supplementary cementitious materials," J. Mater. Civ. Eng., vol. 25, no. 11, pp. 1579-1586, 2013.

[14] H. Zhao, W. Sun, X. Wu, and B. Gao, "The properties of the self-compacting concrete with fly ash and granulated blast furnace slag mineral admixtures," J. Clean. Prod., vol. 95, pp. 66-74, 2015.

[15] E. Worrell, J. A. Laitner, M. Ruth, and H. Finman, "Productivity benefits of industrial energy efficiency measures," J. Energy, vol. 28, no. 11, pp. 1081-1098, 2001.

[16] R. Yu, P. H. J. H. Spiesz, and H. J. H. Brouwers, "Development of an eco-friendly Ultra-High Performance Concrete (UHPC) with efficient cement and mineral admixtures uses," Cement Concr. Compos., vol. 55, pp. 383-394, 2015.

[17] H. F. Campos, T. M. S. Rocha, G. C. Réus, N. S. Klein, and J. Marques Fo., "Determinação do teor ótimo de substituição do cimento Portland por pó de pedra por métodos de empacotamento de partículas e análise do excesso de água na consistência de pastas," RIEM-IBRACON Struct. Mater. J., vol. 12, no. 2, pp. 221-239, 2019. http://dx.doi.org/10.1590/s1983-41952019000200002.

[18] E. F. Felix and E. Possan, "Balance emissions and CO2 uptake in concrete structures: simulation based on the cement content and type," RIEM-IBRACON Struct. Mater. J., vol. 11, no. 1, pp. 135-162, 2018.

[19] M. G. Silva, V. Gomes, and M. R. M. Saade, "Contribuição da avaliação de ciclo de vida na seleção de misturas de concreto de menor impacto ambiental," RIEM-IBRACON Struct. Mater. J., vol. 11, no. 6, pp. 1354-1380, 2018. http://dx.doi.org/10.1590/s198341952018000600010.

[20] C. Varhen, I. Dilonardo, A. D. Figueredo, R. C. O. Romano, and R. G. Pileggi, "Effect of the substitution of cement by limestone filler on the rheological behaviour and shrinkage of microconcretes," Constr. Build. Mater., vol. 125, pp. 375-386, 2016.

[21] M. Grazia, L. Sanchez, R. Romano, and R. Pileggi, "Evaluation of the fresh and hardened state properties of Low-Cement Content (LCC) systems," Mag. Concr. Res., vol. 1, pp. 1-46, 2018. http://dx.doi.org/10.1680/jmacr.18.00271.

[22] M. T. Grazia, L. Sanchez, J. A. F. S. Mesquita, R. C. O. Romano, and R. G. Pilerggi, "Investigation of the use of continuous particle packing models (PPMs) on the fresh and hardened properties of low-cement concrete (LCC) systems," Constr. Build. Mater., vol. 195, pp. 524-536, 2019.

[23] H. F. Campos, N. S. Klein, J. Marques Fo., and M. Bianchini, "Low-cement high-strength concrete with partial replacement of Portland cement with stone powder and silica fume designed by particle packing optimization," J. Clean. Prod., vol. 261, 121228, 2020.

[24] P. K. Mehta and P. J. M. Monteiro, Concreto: Microestrutura, Propriedades e Materiais, 4. ed. São Paulo: IBRACON, 2014.

[25] S. E. S. Mendes, "Estudo experimental de concreto de alto desempenho utilizando agregados graúdos disponíveis na região metropolitana de Curitiba,” M.S. thesis, Univ. Fed. Paraná, Curitiba, 2002.

[26] G. C. Isaia, “O concreto: da era clássica à contemporânea,” in Concreto: Ensino, Pesquisa e Realizações, G. C. Isaia, Ed., São Paulo: IBRACON, 2005, vol. 1, pp. 1-44.

[27] F. G. V. Campos, "CAD: mais que durável, um grande negócio," Rev. IBRACON, vol. 24, pp. 27-34, 2000.

[28] H. G. Costa, Introdução ao Método de Análise Hierárquica: Análise Multicritério no Auxílio à Decisão. Niterói, 2002.

[29] A. Ameri, "Application of the Analytic Hierarchy Process (AHP) for Prioritize of Concrete Pavement," Glob. J. Hum. Soc. Sci. Interdiscip., vol. 13, no. 3, pp. 19-28, 2013.

[30] R. Handfield, S. V. Walton, R. Sroufe, and S. A. Melnyk, "Applying environmental criteria to supplier assessment: a study in the application of the Analytical Hierarchy Process," Eur. J. Oper. Res., vol. 141, no. 1, pp. 70-87, 2002.

[31] N. Pan, "Fuzzy AHP approach for selecting the suitable bridge construction method," Autom. Constr. J., vol. 17, no. 8, pp. 958-965, 2008.

[32] Y. Lai, W. Wang, and H. Wang, "AHP and simulation-based budget determination procedure for public building construction projects," Autom. Constr. J., vol. 17, no. 5, pp. 623-632, 2008.

[33] D. H. Perelles, M. H. F. Medeiros, and M. R. Garcez, "Aplicação da análise hierárquica como ferramenta de tomada de decisão para escolha do compósito de reforço com polímeros reforçados com fibras," Rev. ALCONPAT, vol. 3, no. 4, pp. 165-180, 2013.

[34] J. H. F. Pretto, P. Batista, A. L. Leite, A. C. M. Kormann, M. H. F. Medeiros, and R. B. Boszczowski, "Barreiras verticais de contenção de contaminantes em águas subterrâneas: análise hierárquica," Rev. Geotecnia Lisb., vol. 1, pp. 21-42, 2015.

[35] P. R. M. Grunberg, M. H. F. Medeiros, and S. F. Tavares, "Certificação ambiental de habitações: comparação entre LEED for Homes, Processo Aqua e Selo Casa Azul," Rev. Ambiente Soc., vol. 17, no. 2, pp. 195-214, 2014.

[36] E. Pereira, M. H. F. Medeiros, and S. M. Levy, "Durabilidade de concretos com agregados reciclados: uma aplicação de análise hierárquica," Rev. Ambiente Constr., vol. 12, no. 3, pp. 125-134, 2012.

[37] A. J. Mattana, M. H. F. Medeiros, N. G. Silva, and M. R. M. M. Costa, "Análise hierárquica para escolha entre agregado natural ou areia de britagem de rocha para confecção de argamassas de revestimento," Rev. Ambiente Constr., vol. 12, no. 4, pp. 63-79, 2012.

[38] M. S. Rebmann, "Durabilidade de concretos estruturais com baixo consumo de cimento portland e alta resistência," M.S. thesis, Esc. Eng. São Carlos, Univ. São Paulo, São Paulo, 2011. 
[39] Associação Brasileira de Normas Técnicas, Concreto de Cimento Portland - Preparo, Controle, Recebimento e Aceitação Procedimento, NBR 12655, 2006.

[40] Associação Brasileira de Normas Técnicas, Concreto - Ensaio de Compressão de Corpos de Prova Cilíndricos, NBR $5739,2007$.

[41] Associação Brasileira de Normas Técnicas, Concreto - Determinação da Resistência à Tração na Flexão em Corpos-de-Prova Prismáticos, NBR 12142, 2010.

[42] Associação Brasileira de Normas Técnicas, Argamassa e Concreto Endurecidos: Determinação da Absorção de Água, Índice de Vazios e Massa Específica, NBR 9778, 2005.

[43] Associação Brasileira de Normas Técnicas, Materiais Inorgânicos - Determinação do Desgaste por Abrasão, NBR $12042,1992$.

[44] American Society for Testing and Materials, Standard Test Method for Half-Cell Potentials of Uncoated Reinforcing Steel in Concrete, ASTM C-876, 1991.

[45] Associação Brasileira de Normas Técnicas, Concreto - Determinação do Módulo Estático de Elasticidade à Compressão, NBR $8522,2008$.

[46] C. A. G. Gregório, "Método para análise de oportunidades de imobilização em imóveis corporativos,” M.S. thesis, Esc. Politéc., Univ. São Paulo, São Paulo, 2010.

Author contributions: S. R Pinto: conceptualization, methodology, analysis, writing. D. H. de Bem: conceptualization, methodology, analysis, writing. M. S. Rebmann: conceptualization, methodology, data acquisition, experimental procedures, analysis, writing. M. H. F. de Medeiros: conceptualization, methodology, supervision, writing.

Editors: Edna Possan, José Luiz Antunes de Oliveira e Sousa, Guilherme Aris Parsekian. 